УДК 339.165.4-049.5(045)

JEL Classification H 10, G 35, O 14, O 16

DOI 10.31375/2226-1915-2021-2-5-15

\section{МОРСКАЯ ТРАНСПОРТНАЯ ИНДУСТРИЯ И СИСТЕМНАЯ ЭКОНОМИЧЕСКАЯ БЕЗОПАСНОСТЬ}

\section{Н.Т. Примачев}

д.э.н., профессор кафедры

«Экономическая теория и предпринимательство на морском транспорте» prima.nik1@yandex.ru ORCID: 0000-0003-0192-2894

Национальный университет «Одессская морская академия, Одесса, Украина

Аннотация. Современные экономиче ские приоритеты, предопределяющие устойчивость развития международной торговли, предопределяют повышение роли морского транспорта как в бизнес-деятельности, так и в социиальной и экологической сферах. При этом следует учитывать, что затраты по обеспечению этих результатов концентрируются в системе морской транспортерной индустрии. Результативность их в значительной мере образуется в форме эмерджентного эффекта. Одновременно подсистемы морской транспортной индустрии в отличие от других видов деятельности регулируются в значительной степени международными институтами. То есть инвесторь торгового флота и морских портов должнь ориентироваться не только на предпринимательские иели, но на внешние ограничения их конкурентной реализации. Таким образом проблемой становится сбалансированность экономической безопасности $u$ общесистемной безопасности деятельности предприятий морского транспорта. Все отмеченное требует выбора методов управления и поддержания подсистем морской транспортной индустрии с позиции системной безопасности. В свою очередь требуется уточнение сущности этой категории с обеспечением вышеуказанного, что впоследствии усилит устойчивость и надежность морской индустрии как по отдельным ее составляяющчим, так и на международном уровне.

Ключевые слова: системная сбалансированность, экономическая эффективность, безопасность, системный результат.
УДК 339.165.4-049.5(045)

JEL Classification H 10, G 35, O 14, O 16

DOI 10.31375/2226-1915-2021-2-5-15

\section{МОРСЬКА ТРАНСПОРТНА ІНДУСТРІЯ I СИСТЕМНА ЕКОНОМІЧНА БЕЗПЕКА}

\section{М.Т. Примачов}

д.е.н., професор кафедри

«Економічна теорія та підприємництво на морському транспорті» prima.nik1@yandex.ru ORCID: 0000-0003-0192-2894

Наиіональний університет «Одеська морська академія, Одеса, Украӥна

Анотація. Сучасні економічні пріоритети, які спричиняють стійкість розвитку міжнародної торгівлі, зумовлюють підвищення ролі морського транспорту як в бізнес-діяльності, так $і$ в сочуільній та екологічній сферах. При цуьому слід враховувати, щзо витрати по забезпеченню цих результатів концентруються в системі морської транспортерної індустрії. Результативність їх значною мірою утворюється у формі емерджентного ефекту. Одночасно підсистеми морської транспортної індустрії на відміну від інших видів діяльності регулюється значною мірою міжнародними інститутами. Тобто інвестори торгового флоту $і$ морських портів повинні орієнтуватися на тільки на підприємницькі ияілі, але на зовнішні обмеження їх конкурентної реалізації. Таким чином проблемою стає збалансованість економічної безпеки і загальносистемної безпеки діяльності підприсмств морського транспорту. Все зазначене вимагає вибору методів управління $i$ підтримки підсистем морської транспортної індустрії з позииіі системної безпеки. У свою чергу потрібне уточнення сутності ичієї категорії з забезпеченням вищевказаного, ччо згодом посилить стійкість $i$ надійність морської індустрї̈ як по окремим іï складовим, так і на міжнародному рівні.

Ключові слова: системна збалансованість, економічна ефективність, безпека, системний результат.

(C) Примачев Н.Т., 2021 
UDC 339.165.4-049.5(045)

JEL Classification H 10, G 35, O 14, O 16

DOI 10.31375/2226-1915-2021-2-5-15

\title{
SEA TRANSPORT INDUSTRY AND SYSTEM ECONOMIC SECURITY
}

\author{
Nicholas Primachev \\ DEcon, professor, head of Department of \\ «Economic Theory and Entrepreneurship in Maritime Transport» \\ prima.nik1@yandex.ru \\ ORCID: 0000-0003-0192-2894
}

National University «Odessa Marine Academy» Odessa, Ukraine

\begin{abstract}
Modern economic priorities, which predetermine the sustainability of the development of international trade are also predetermining the increase in the role of maritime transport in both business activities, - social and environmental spheres. It should be borne in mind that the costs of ensuring these results are concentrated in the system of the sea conveyor industry and are used to be strictly relevant. Their effectiveness is largely displayed in the form of an emergency effect, which highly affects the demand of the consumers, which is, in its turn forms the amount of the provided services within the sea transport industries. At the same time, the subsystems of the maritime transport industry, in contrast to other activities, are governed by the international institutions which are also affecting the total results of their productions or transportation processes. Concerning the other part of the system, the investors of the merchant fleet and seaports should be focused not only on the entrepreneurial purposes, but on the external restrictions on their competitive implementation as well. Thus, one of the main problems is based on the balance of economic security and the system-wide security of the activities of enterprises of the maritime transport. It should be borne it mind that these particulars of the maritime transport, such as its port industry, the transportation system, the logistics operations and other necessary parts and spheres are highly connected and are very dependent on the maritime industry. The mentioned above information requires the choice of the management methods and maintaining the subsystems of the maritime transport industry from the system security. In turn, it is necessary to clarify the essence of this category with the provision of the above, which will subsequently strengthen the stability and reliability of the maritime industry both by the individual components and internationally. As far as known, the maritime transport is built on many different certain parts and organizations most of which cannot exist without each other.
\end{abstract}

Keywords: international trade, maritime transport, industry, effect of emergency, economic security. 
Постановка проблеми. Світова торгівля як найважливіша умова економічного зростання, як відомо, в значній мірі підтримується підприємствами морського транспорту [1]. У свою чергу збалансованість світової економіки в значній мірі визначає розвиток морського транспорту і стає найважливішим фактором сучасного розподілу морського транспортного потенціалу по постіндустріальним країнам. Це додатково підкреслює його емерджентну роль. Морська транспортна індустрія по результативності, економічності, ресурсоємності та характером техногенного впливу на природу $є$ унікальною в порівнянні 3 іншими видами економічної діяльності.

Морська транспортна індустрія, функціонуючи в єдиному світовому ринку i в окремих його складових зберігає жорсткі відмінності і виявляє властиві тільки їй закономірності.

В основі стійкості сучасної структури економічного розвитку лежать чотири основи формування системної безпеки. Перша - це досягнення стійкої платоспроможності мікро- і макроекономічних підсистем. Друга - збереження умов природної рівноваги при будь-яких економічних пріоритетах. Третя - досягнення фізичної безпеки для життя людей i капітальних активів. I четверта макроекономічна стабільність країни в міжнародних відносинах $\mathrm{i}$ щодо внутрішнього соціально-економічної рівноваги [2].

Огляд останніх досліджень та літератури. У торговельному судноплавстві принципи кількісних і якісних змін істотно відрізняються від загальної тенденції ринкових про- цесів. Така відмінність має дві основні причини. По-перше, це обумовлюється сферою операторської діяльності. По-друге, це обумовлюється системною значущістю морської транспортної індустрії в технології забезпечення стійкості глобальних відносин. Конкретна ситуація на ринку морської торгівлі залежить від точного побудови даних, як якісних так і кількісних змін, що зумовлює подальше використання технологій виробництва, а також наслідок ефективності експлуатування морського транспорту за отримані кошти відповідно до прибутковості перевезень [3].

Постановка задачі. Соціальноекономічний статус підприємницької діяльності не обмежується тільки чистими інтересами власників капітальних активів. Підприємства морського транспорту створюють значний синергетичний i емерджентний ефекти. При цьому підприємства морського транспорту знаходяться в жорсткій залежності від характеру прояву негативних екзогенних ситуацій.

Основний матеріал дослідження. Діяльність морського транспорту відрізняється порівняно низькою капіталомісткістю, трудомісткістю і негативним впливом на навколишне середовище. Проте, саме морський транспорт у найбільшій мірі схильний до глобальних регуляторних процесів 3 позиції оптимізації позатранспортних результатів. Саме останне призводить до істотного зниження підприємницької ефективності при помітному зростанні позасистемного результату. 
DEVELOPMENT OF MANAGEMENT

AND ENTREPRENEURSHIP METHODS ON TRANSPORT, № 2 (75), 2021
РОЗВИТОК МЕТОДІВ

УПРАВЛІННЯ ТА ГОСПОДАРЮВАННЯ

НА ТРАНСПОРТІ, № 2 (75), 2021
Щодо принципів нормалізації стану морської транспортної індустрії, як відомо, морський транспорт забезпечує перевезення понад 80 відсотків товарів міжнародної торгівлі, що у вартісному вираженні перевищує 30 трильйонів доларів. При цьому капітальні активи торговельного флоту знаходяться в межах 1,7 трильйона доларів.

Це становить близько 1 відсотка капітальних активів, що беруть участь у формуванні продукції зовнішньої торгівлі, яка доставляється до місць реалізації морським транспортом. Отже, морська транспортна індустрія виявляється по сприйманню цінності найбільш ефективною по інвестиційним потокам.

Чисельність фахівців, зайнятих на перевезеннях і в системі управління транспортним процесом не перевищує 2 мільйонів чоловік. Щодо використовуваних капітальних ресурсів, надання послуг загального обсягу вантажопотоків світової торгівлі і чисельності працівників морський транспорт по економічності не має аналогів. При цьому в порівнянні 3 іншими галузями світової економіки цей сегмент праці виявляється мінімальним i за характером створення негативного навантаження на природу.

Наведені параметри основних економічних показників морської транспортної індустрії підкреслюють не тільки ії глобальну значимість, але i жорстку залежність від несприятливих екстерналій. Для забезпечення високої ефективності з позиції резидентів зовнішньої торгівлі підприємства морського транспорту повинні постійно нарощувати виробничий потенціал і мати певні резерви для виконання додаткових вантажопотоків.

У той же час будь-які негативні трансформації в економічних відносинах в світовій економіці найбільш жорстко відбиваються на економічному становище судноплавних $\mathrm{i}$ стивідорних компаній.

Одночасно фактично 3 позиції одиничної потужності силових установок суден непередбачені зміни вартості суднового палива обумовлюють втрату економічної стійкості компанії і постійної необхідності пошуку шляхів підвищення економічності споживання енергетичних ресурсів.

Які б форми економічної підтримки на макрорівні не використовувалися в системі морської транспортної індустрії, основним фактором стійкості глобальних економічних відносин залишається активність підприємницької діяльності в торговельному судноплавстві та відповідність стандартам Міжнародної морської організації. Саме це зумовлює адекватність пропозиції провізної здатності флоту загальносвітовим потребам.

Тому будь-які регуляторні підходи в системі ринку морської торгівлі повинні враховувати пріоритетність нормалізованої діяльності підсистем морської транспортної індустрії [3]. Будь-які рішення 3 позиції глобальних економічних інтересів не повинні ігнорувати базові позиції розвитку судновласницькі структур, діяльність яких забезпечує в певному статусі світову економіку.

Зазначені вище економічні переваги морської транспортної індустрії та іiі значущість для стійкості 
міжнародних економічних відносин передбачає використання принципу загальносистемної безпеки. У даному випадку розуміється проведення всіх необхідних трансформацій не лише за рахунок окремих підприємницьких структур, але й розуміється вираховування раціональності формування синергії і збереження всієї сукупності інтересів.

Щодо проблем досягнення збалансованості інтересів у системі ринку морської торгівлі, необхідно чітко оцінювати економічні втрати підсистем морської транспортної індустрії та глобальні економічні наслідки зниження пропозиції якісної провізної здатності флоту. У цілому системна результативність роботи, а, отже, i розвитку морського транспорту полягають у формуванні:

- ефекту вантажовласників (емерджентна форма);

- економічного ефекту підприємств морського транспорту;

- ефекту формування складових економічної концентрації або кластера; вища;

- ефекту навколишнього середо-

- зростання ВВП за такими чинниками стимулювання нових виробництв і відповідних робочих місць.

Регуляторні дії з боку глобальних інститутів змінюють співвідношення різних складових системного ефекту внаслідок перенесення центрів витрат і формування нових центрів результативності функціональної діяльності підсистем морської транспортної індустрії. У системі управління збалансованістю необхідно враховувати перерозподіл емерджент- ного ефекту і раціоналізація використання ефекту синергії.

Пандемія 2020 року висвітлила вразливість не тільки життя людини, але ще більшою мірою підкреслила роль економіки для цього життя i одночасно залежність економіки від рішень, які не відповідають стабілізації життєвого простору. Особливо жорстко це проявилося у виробничій індустрії.

Традиційно серед принципів ефективного розвитку виділяється націленість на зростання доданої вартості по всьому ланцюгу національної економіки 3 урахуванням глобальних зовнішніх обмежень [4]. У загальному вигляді 3 урахуванням характеру впливу зовнішніх регуляторних умов додана вартість роботи морського транспорту, як джерела підприємницької та позасистемної ефективності формується за умовою

$\Delta R_{v d}=\sum R_{v i}-\sum C_{s t b}-\Delta C_{s t g} \rightarrow \max$

де $\Delta R_{v i}$ - доходи судновласницьких або портових компаній, які спормовані за поточних умов ринку морської торгівлі при раціональному використанні капітальних активів власника i праці працівників;

$\sum C_{s t b}-$ зовнішні витрати підприємств морського транспорту, пов'язані 3 оплатою ресурсів і послуг, отриманих від інших учасників ринку;

$$
\Delta C_{s t g} \quad-\text { додаткові зовнішні }
$$

витрати, зумовлені регуляторним механізмом 3 боку глобальних i національних інститутів, які контролюють відношення 3 безпеки природних ресурсів. 
DEVELOPMENT OF MANAGEMENT AND ENTREPRENEURSHIP METHODS ON TRANSPORT, № 2 (75), 2021
РОЗВИТОК МЕТОДІВ

УПРАВЛІННЯ ТА ГОСПОДАРЮВАННЯ

НА ТРАНСПОРТІ, № 2 (75), 2021
Таким чином, у процесі діяльності підприємств морської транспортної індустрії будь-якої держави формується два основних ефекти. Перший - чисто економічна діяльність власника капітальних ресурсів і ресурсів, придбаних на ринку. Другий - позатранспортна складова в формі сприйняття цінності користувачів транспортних послуг та оптимізація стану природного середовища.

На жаль, зовнішня результативність розвитку та роботи підсистем морської транспортної індустрії вимагає 3 боку морського транспорту значних витрат, які істотно знижують підприємницьку результативність. 3 урахуванням різниці результатів діяльності судноплавних компаній $\mathrm{i}$ торговельних портів внаслідок зростання їх витрат виникає проблема компенсації витрат, що забезпечують емерджентним ефектом.

У цьому відношенні слід розрізняти i центри управління торговельним судноплавством. Одні власники капітальних активів або оператори. Інші - глобальні морські інститути. Але витрати концентруються у перших.

Саме для глобального ринку морської торгівлі характерна наявність обмеженої кількості координат, які і зумовлюють закономірності, які важливо підтримувати. Ряд їх очевидний, - інші вимагають спеціального розгляду. Складність полягає в тому, що використання світового океану - найдавніший і дуже стійкий процес.
При цьому проблемою залишається, незважаючи на розвиток інформаційних технологій, тимчасова обмеженість прогнозів стану ринку морської торгівлі, що збільшує ризики судновласників внаслідок зростання питомої капіталомісткості одиниці виробничого потенціалу. Це ж положення ускладнює побудову соціально-економічної моделі ефективного позиціювання автономного судноплавства в системі симетрії відносин, які зумовлюють основні складові ринку морської торгівлі (рис. 1).

Системна безпека сучасних економічних відносин базується на досягненні нормальної підприємницької діяльності, яка характеризується підприємницькими інтересами і гідним рівнем життя працівників [5]. Екстернальними обмеженнями цього підходу стають вимоги щодо збалансованості відносин у навколишньому середовищі. Це фактично інноваційний підхід, що відрізняється від традиційних пріоритетів власників капітальних активів. Фактично потрібна переоцінка ролі окремих результатів господарської діяльності не $з$ позиції економмічних операторів, а з позиції загальносистемних вимог. Відсутність практики такого підходу і зумовлює складність сприйняття цього процесу підприємницькими структурами. 3 іншого боку, інтереси глобальної рівноваги, концентрація уваги на емерджентних результатах роботи підсистем морської транспортної індустрії вимагає чіткості розподілу ефекту синергії. 


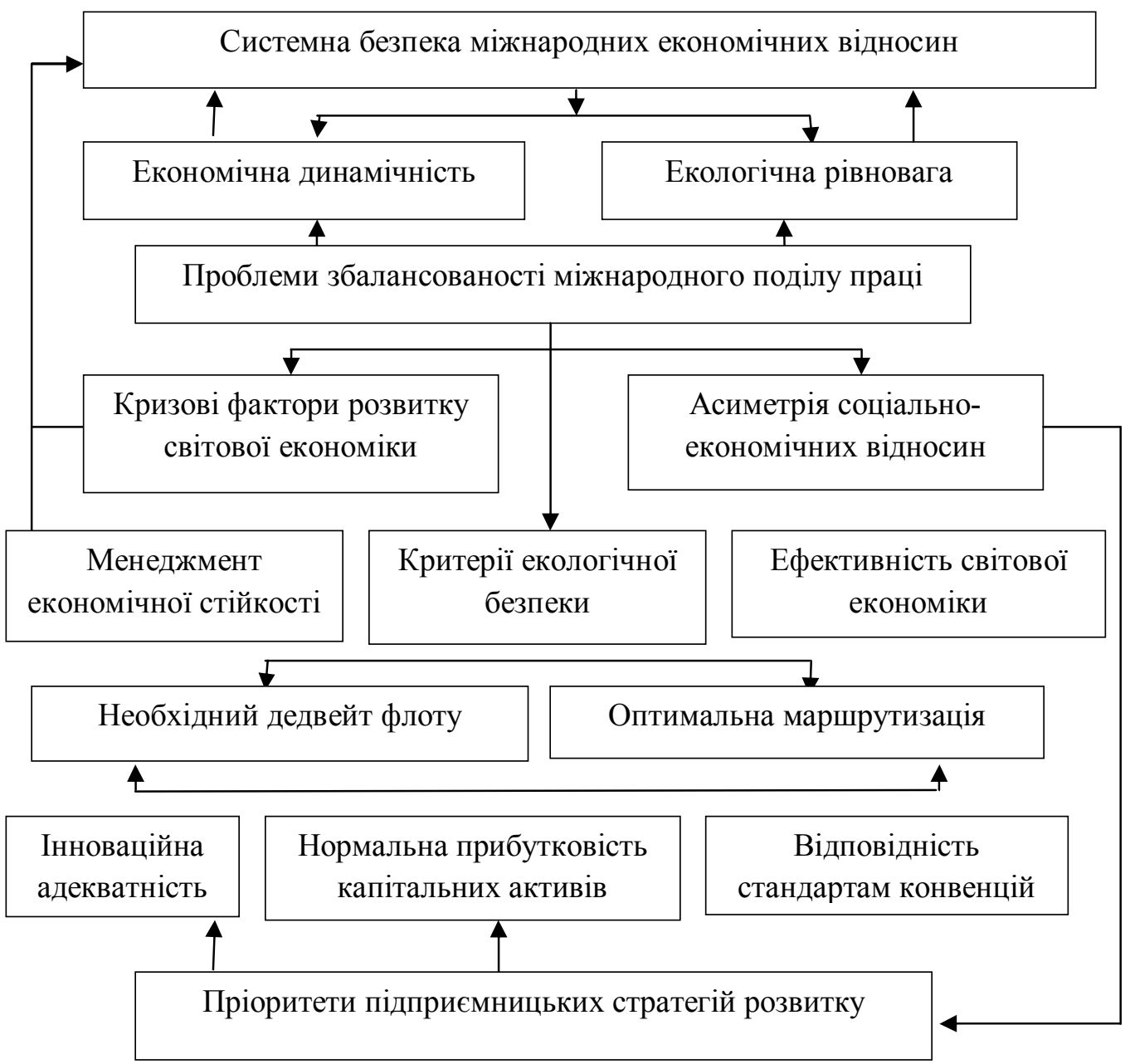

Рисунок 1. Умови формування системної безпеки розвитку підсистем світової економіки

Джерело: власна розробка автора

Будь-яка стратегія економічного зростання [6] повинна відображати пріоритет забезпечення умов стандартної по задоволенню потреби життя особистості. Це один із критеріїв соціально-економічного розвитку будь-якої держави. Саме ступінь реалізації цієї проблемної задачі і визначає сучасне угрупування держав.
Реалізація проекту автономного судноплавства на базі «розумних» суден обумовлює появу нових соціально-економічних проблем на національному і глобальному рівні [7]. Скорочення чисельності моряків 3 відносно високою оплатою праці приведе до зниження споживчого попиту, що в кінцевому рахунку позначиться 
DEVELOPMENT OF MANAGEMENT AND ENTREPRENEURSHIP METHODS ON TRANSPORT, № 2 (75), 2021 не тільки на знижених темпах виробництва, але й в кінцевому рахунку на відповідних вантажопотоках.

Проте, пріоритети підприємницьких стратегій залишаються провідною силою поступального розвитку. I зміна традиційних (базових) підходів вимагає виділення інституціональних інструментів підтримки системних (кластерних) інтересів [8].

Складним виявляється процес економічної динамічності при принципах забезпечення екологічної рівноваги. Справедливого вирішення цієї проблеми можна досягти при нівелюванні підприємницьких втрат одних за рахунок перерозподілу емерджентних результатів і витрат. Однак такий інструментарій не розроблений через складність вирішення проблеми з позиції інтересів підприємницьких, макроекономічних і глобальних результатів.

Отже, важливим $є$ положення, при якому необхідно управління не окремими результатами, а всім комплексом ефективного позиціювання підприємницьких структур 3 позиції прямих і системних результатів.

Проблеми збалансованості поділу міжнародного праці, з одного боку, зумовлюють ризики сталого позиціонування обізнаних судноплавних компаній, а, 3 іншого, виявляються під впливом асиметрії розвитку морської транспортної індустрії морських держав.

Цій фактор за критеріями ринкових відносин перетворюється в певну закономірність, яку повинні враховувати в системі ризиків судновласницької структури.

При цьому необхідно диференціювати реакцію на фактори кризо- вого стану ринку морської торгівлі, одні 3 яких зумовлюються загальносистемними стратегіями економічного розвитку, а інші обумовлені внутрішньогалузевими факторами.

Асиметрія соціально-економічних відносин, обумовлена нерівномірністю і некомплексністю розвитку окремих держав, що породжує проблеми розвитку ряду економіки i породжує, як це було реалізовано між США і Китаєм деформацію сформованих в межах існуючих регуляторних принципів СОТ.

Внаслідок прояви системи факторів, що впливають на вибір параметрів морської транспортної індустpii,, виникає необхідність створення механізму та інструментарію управління збалансованістю підсистем морської транспортної індустрії. У цьому аспекті формується менеджмент утримання або зростання прибутковості капітальних активів судноплавних компаній i торговельних портів.

Відповідний стан глобальної морської транспортної індустрії певним чином впливає на ефективність світової економіки. Однак, крім вирішення соціально-економічних проблем зростає роль досягнення екологічної збалансованості господарських процесів. Тому глобальні інституційні системи формують відповідні критеpiï екологічної адекватності будьякого виробничо-економічного рішення [9]. Останнє вирішується фактично на основі зниження підприємницької ефективності, що і веде до негативної реакції, наприклад, США на систему природоохоронних проектів - Паризького меморандуму. 
Тому і виникають завдання формування системної безпеки, що відображає необхідність створення і підтримки робочих місць по підприємницькій ефективності, а також формування витрат по екологічній безпеці та забезпеченню макроекономічної рівноваги.

Реакцією на характер сформованих умов або обмежень стає вибір і формування відповідного типоразмірного ряду суден щодо маршрутизації вантажопотоків. Таким чином формується базова складова підприємницької діяльності з позиції збалансованості інтересів попиту і пропозиції.

При прояві вимог глобальних i національних інститутів i виникає необхідність пошуку нових рішень 3 позиції збалансованості інтересів.

Висновки. Спочатку і в кінцевому рахунку в основі пріоритетів розвитку судновласницькі структур i торговельних портів лежить підприємницький пріоритет - норма прибутковості капітальних активів. Цим і зумовлюється стратегія розвитку на основі досягнення інноваційних переваг 3 урахуванням стандартів системної безпеки як з позиції макроекономічних інтересів, так і 3 ура- хуванням стандартів IMO та інших глобальних регуляторів.

Необхідно враховувати, що дисбаланс в системі глобального ринку морської торгівлі зумовлюється змінами в темпах і розвитку держав і в мінливості напрямків зовнішньої торгівлі [1]. Тому залишається ризик управління ефективністю формування i використання капітальних активів. Але незмінним стає принцип обмеження негативного впливу на природне середовище. Тому при проектуванні суден та вантажних терміналів останній фактор повинен відображатися в інвестиційній діяльності по більш жорстким стандартам, тобто вибирати варіант розвитку, який не обмежується наступним посиленням екологічних стандартів.

Як регулятор морських транспортних маршрутів, що обумовлюють використання виробничого потенціалу портів, є економічність і час доставки товарної маси за критеріями оптимальності реалізації відповідного оборотного капіталу вантажовласників. У цьому аспекті слід реалізувати i інвестиційні програми, які націлені на мінімізацію складової ціни виробництва.

\section{ЛІТЕРАТУРА}

1. Review of Maritime Transport. Report by the UNCTAD - New York and Geneve: UN, 2019. 167 p.

2. Сакс Дюс. Д. Макроэкономика. Глобальный поход. М.: Дело, 1996. 847 с.

3. Birn R.J. The Handbook o International Market research techniques. London: Kogan page, 2003, $594 \mathrm{c}$.

4. Кругман П.Р. \& М. Обстфельд. Международная экономика. СПб.: Питер, 2003. $832 \mathrm{c}$.

5. Колегаєв I.М. Принциии комплексного розвитку спеціалізованого судноплавства глобальної морської індустрії. Одеса: НУ «ОМА», 2017. $332 \mathrm{c}$. 
6. Л Ламбен Ж.Ж. Менеджмент, ориентированный на рынок. СПб.: Питер, 2006. $800 \mathrm{c}$.

7. Портер М. Конкурентная стратегия: Методика анализа отраслей и конкурентов; М.: Альпина Бизнес Букс, 2006. 454 с.

8. Сенько О. В. Організачійно-економічний механізм параметричного управління морською транспортною індустрією. Чернігів: ЧНТУ, 2019. $359 \mathrm{c.}$

9. Stepniak A., Zielinski M. Unia Europejska jako partner globalny. Co to oznacza dla Polski? Gdansk: 2018 // Studia i materialy instytutu transport I hanflu morskiego. P. 159-182

10. Котлубай А.М. Проблемь теории и практики развития морского транспорта Украины. Одесса: ИПРиЭЭИ НАН Украины, 2011. 268 c.

11. Моряков К. Проект для развития морской отрасли // Порты Украины, № 1 (173) 2018. С. 32-35

12. Аткиссон А. Как устойчивое развитие может изменить мир. М.: БИНОМ, 2011. $455 \mathrm{c}$.

13. Внедрение сбалансированной системы показателей. М.: Альпина Бизнес Букс, 2006. 478 c.

14. Дамодаран А. Інвестищійна оцінка: Інструменти і техніка оцінки будьяких активів. М.: Альпіна Бізнес Букс, 2004. 1342 с.

15. Гохан П.А. Слияния, поглощения и реструктуризаџия компаний, 2018. $742 c$.

\section{REFERENCES}

1. Review of Maritime Transport. Report by the UNCTAD - New York and Geneve: UN, 2019. 167 .

2. Sax, J.D. (1996). Makroekonomika. Global'nyy pokhod [Macroeconomics. Global campaign]. M.: Case, 847. [in Russian].

3. BIRN, R.J. (2003). THE HANDBOOK O INTERNATIONAL MARKET Research Techniques. London: Kogan Page, 594 p.

4. Krugman, P.R. \& Obstfeld, M.. (2003). Mezhdunarodnaya ekonomika [International Economics]. SPb.: Peter, 832. [in Russian].

5. Kolegaev, I.M. (2017). Pryntsypy kompleksnoho rozvytku spetsializovanoho sudnoplavstva hlobal'noyi mors'koyi industriyi [Principles of Complex Division of the Special Regional Site of Global Maritime Industry] Odessa: Well, Oma, 332. [in Ukrainian].

6. Lamben, J.Zh. (2006). Menedzhment, oriyentirovannyy na rynok [Management oriented on market]; SPb.: Peter, 800. [in Russian].

7. Porter, M. (2006). Konkurentnaya strategiya: Metodika analiza otrasley $i$ konkurentov [Competitive strategy: Methods of analyzing industries and competitors]. Alpina Business Buks, 454. [in Russian]. 
8. Senko, O.V. (2019). Orhanizatsiyno-ekonomichnyy mekhanizm parametrychnoho upravlinnya mors'koyu transportnoyu industriyeyu [Organizational and economic mechanism of parametric management of the maritime transport industry] Monogr. Chernigiv: ChNTU, 359 [in Ukrainian].

9. Stepniak, A., Zielinski, M. Unia Europejska Jako Partner Globalny. Co to oznacza dla polski? [Zielinski, The European Union As A Global Partner. What does this mean for Poland?]. Studia I Materialy Instytutu Transport I Hanflu Morskiego - Studies and materials of the Institute of Maritime Transport. Gdansk: 2018, P. 159-182. [in Polish].

10. Kotlubay, A.M. (2011). Problemy teorii $i$ praktiki razvitiya morskogo transporta Ukrainy [Problems of the theory and practice of the development of the maritime transport of Ukraine]. Odessa: National Academy of Sciences of Ukraine, 268. [in Russian].

11. Sailors, K. (2018). Proyekt dlya razvitiya morskoy otrasli [Project for the development of the maritime industry]. Porty Ukrainy - Ports of Ukraine, No. 1 (173) P. 32-35. [in Russian].

12. Atkisson, A. (2011). Kak ustoychivoye razvitiye mozhet izmenit' mir [How sustainable development can change the world]. M.: Binom, $455 p$.

13. M.: Alpina (2006). Vnedreniye sbalansirovannoy sistemy pokazateley [Implementation of a balanced system of indicators] 478. [in Russian].

14. Damodaran, A. (2004). Investytsiyna otsinka: Instrumenty i tekhnika otsinky bud'-yakykh aktyviv [Investment Valuation: Tools and techniques for valuing any assets] M.: Alpina Biznes Buks, 1342. [in Ukrainian].

15. Gohan, P.A. (2018). Sliyaniya, pogloshcheniya i restrukturizatsiya kompaniy [Merger, absorption and restructuring of companies]. 742. [in Russian].

Стаття надійшла 25.05.2021

Посилання на статтю: Примачев М.Т. Морська транспортна індустрія і системна економічна безпека // Розвиток методів управління та господарювання на транспорті: Зб. наук. праць, 2021. № 2 (75). С. 5-15. DOI 10.31375/2226-1915-2021-2-5-15.

Article received 25.05.2021

Reference a JournalArtic: Primachev Nicholas (2021). Sea transport industry and system economic security. Development of management and entrepreneurship methods on transport. 2 (75), 5-15. DOI 10.31375/2226-1915-2021-2-5-15. 